\title{
How does learning keep a small company afloat?
}

\author{
Genevieve Hundermark \\ Monash South Africa Foundation Programme, South Africa \\ genevieve.hundermark@monash.edu
}

\begin{abstract}
Small and medium enterprises in South Africa experience one of the highest failure rates in the world with approximately $90 \%$ failing in their first ten years, suggesting that few are sustainable entities. In order to be sustainable, organisations should be learning ones. Senge's (1990) ground-breaking model of a learning organisation, previously researched in large global companies, was used as the basis of researching a small company in South Africa. The study explored whether by being a learning organisation, the company could sustain itself. Senge's model includes five disciplines, with embedded adult learning theories. An ethnographic case study attempted to identify whether the company drew on these learning theories in its operations, and if this contributed to its development as a learning organisation. The study revealed an interesting blend of a business management concept with adult education principles that gave insight into developing the small company as a learning organisation.
\end{abstract}

Keywords: Small business sustainability, small business management, learning organisations, adult learning theories, Organisational learning

\section{Introduction}

In South Africa, small and medium enterprises (SMEs) are an important sector - they contribute approximately half of total employment (Cant, 2012, p. 1107) and more than $30 \%$ of total gross domestic product (GDP) (Olawale \& Garwe, 2010, p. 729). SMEs play a critical role in developing national economies, alleviating poverty, creating jobs and participating in the global economy and creating economic growth and equity (Republic of South Africa. Department: Trade and Industry, n.d.; PainterMorland \& Dobie, 2009; World Business Council for Sustainable Development (WBCSD) \& SNV, 2007). Small companies in South Africa find it difficult to sustain themselves. 40\% of new SMEs fail in their first year, $60 \%$ in their second year, and $90 \%$ in their first ten years (Cant, 2012, p. 1107). In order to survive, or be sustainable, "...organisations must learn faster and adapt to the rapid change in the environment" (Marquardt, in Hattingh \& Smit, 2004, p. 2) and as such should be learning. If they do not survive, South Africa loses jobs and GDP. This paper is based on a study consisting of two research periods, one in 2008, the other in 2012, of a small South African company, based in Gauteng, which consults in the mining sector. Their consulting practice includes operational readiness and capital projects. There were on average 16 organisation members during both research periods, consisting of a managing director, finance manager, capital projects manager, operational readiness manager, marketing manager, office manager and ten consultants. The business had been operational for approximately 15 years and for this reason was selected as the research site.

The study revealed an interesting blend of a business management concept ("the learning organisation") with adult education principles that give insight into developing a small company as a learning organisation. The study is based on Peter Senge's model of a learning organisation, which states that to be sustainable, organisations should be learning ones, "where people continually expand their capacity to create the results they truly desire, where new and expansive patterns of thinking are nurtured, where collective aspiration is set free, and where people are continually learning how to learn together" (Senge, 1990, p. 3). Senge has many critics. For example, his idea of a learning organisation has been criticised as being 'cuddly', 'idealistic' with surreptitious motives and inadequate in addressing power relations (Fenwick, 2001; Garvin, 1993; Tight, 1996). However, the model does contribute to a conducive and empowering working environment, where organisation members can be valued. In the context of South Africa with its Apartheid legacy (and the consequent dehumanising of black people), the model seems to be a worthwhile one to pursue. The study had as its focus the following research question and subquestions:

- How is the concept of a learning organisation taken up in a small company?

- What facets of a learning organisation are reflected in the company? 
- What does sustainability mean in the context of the small company?

- How can facets of a learning organisation be corrected or strengthened in the company in order to contribute to its sustainability?

The case study is likely to be of interest to small business owners and managers in South Africa, small business researchers, and consultants in the field of small business and adult or workplace education and learning.

\section{Literature Review}

The literature that was pertinent to this study included defining what a learning organisation is; Senge's (1990) model of a learning organisation; learning theories embedded in Senge's disciplines of a learning organisation; small business sustainability; and the role of small business leadership in creating the culture of a learning organisation and leading a small business.

What is a learning organisation? It can be said that the view of organisation members determines if the organisation is a site of learning that engages in the process of learning, produces and practises learning (Rogers, 2003). If an organisation engages in all three, it can be seen to be a learning organisation. However, Senge (1990) suggests that five disciplines should be practised in organisations so that they may be learning ones and sustainable entities. The five disciplines, namely systems thinking, personal mastery, mental models, building shared vision and team learning, can be developed separately but each is critical to the success of the others. The disciplines are intrinsically linked to various learning theories that can assist in developing the disciplines, both individual and workplace. These learning theories can inform the practice of a learning organisation. The learning theories are indicated in Table 1.

\section{Table 1: Embedded learning theories in learning organisation disciplines}

\begin{tabular}{|c|c|}
\hline Learning organisation discipline & Embedded organisational learning theories \\
\hline \multirow[t]{6}{*}{ Systems thinking } & Double-loop, generative learning \\
\hline & Triple-loop learning \\
\hline & Activity Theory/Cultural-Historical Activity Theory (CHAT) \\
\hline & Actor-Network Theory (ANT) \\
\hline & Communities of Practice \\
\hline & Complexity Theory \\
\hline \multirow{3}{*}{ Personal mastery } & Action learning \\
\hline & Triple-loop learning \\
\hline & Communities of Practice \\
\hline \multirow[t]{3}{*}{ Mental models } & Triple-loop learning \\
\hline & Communities of Practice \\
\hline & Complexity Theory \\
\hline \multirow{3}{*}{ Building shared vision } & Collaborative learning \\
\hline & Triple-loop learning \\
\hline & Communities of Practice \\
\hline \multirow[t]{7}{*}{ Team learning } & Collaborative learning \\
\hline & Action learning \\
\hline & Single-loop learning \\
\hline & Double-loop learning \\
\hline & Triple-loop learning \\
\hline & Communities of Practice \\
\hline & Complexity Theory \\
\hline
\end{tabular}

Learning disciplines: Systems thinking recognises the interdependency of the disciplines and enables organisation members to view the entire system as a whole and "make the full patterns clearer", helping members see "how to change them effectively" (Senge, 1990, p. 7). This discipline drives a learning organisation and assists it to meet the demands of the environment in which it operates, contributing to its sustainability. Personal mastery is concerned with members of an organisation clarifying and deepening personal vision, focussing energies, developing patience and seeing reality objectively. This discipline enables members to serve their highest hopes and desires (Senge, 1990, p. 8), encouraging them to commit to lifelong learning and so contributing to the organisation is being a learning one. Mental models "are deeply ingrained assumptions and generalisations... that influence how we understand the 
world and how we take action" (Senge, 1990, p.8). "Learningful" conversations should take place in the organisation to assist members to expose and challenge their assumptions effectively and to have their thinking open to the influence of others. Critical reflection, which is about questioning a situation, or information, rather than accepting it at face value (Brookfield, 2000; Mezirow, in Mezirow and Associates, 1990), is key to this practice. Building shared vision is a discipline that involves creating a genuine vision that members want to commit to and "involves the skills of unearthing shared pictures of the future" (Senge, 1990, p. 9) that encourage members to excel and learn. "Learningful" conversations can encourage this. Team learning begins with dialogue where team members partake in an authentic "thinking together" by initially revealing their assumptions to the rest of the team to identify if stumbling blocks exist that undermine learning. If teams cannot learn, then the organisation cannot learn (Senge, 1990, p. 10).

Learning theories: The learning theories that underpin the five disciplines as indicated in Table 1 lend themselves to enhancing the practice of the learning disciplines. Although the various learning theories help to explain how organisations learn, for the purposes of this paper, triple loop learning and communities of practice will receive attention. As can be seen from Table 1, these theories relate to all five disciplines and if these two theories are practised, then a company is likely to be a learning organisation.

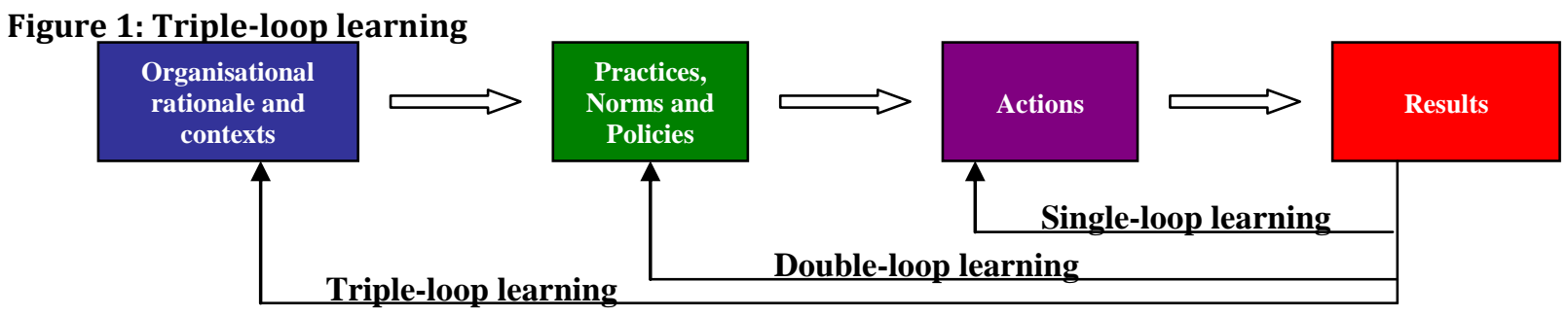

Triple-loop learning is concerned with questioning key principles on which the organisation is based, inquiring into and challenging the underlying "why's" of the organisation's mission, vision, market position and culture (Altman \& Iles, 1998; Isaacs, 1993). Triple-loop learning relates to the very purpose of our individual being or existence, where we question who we are and how that impacts on what we do, how we act and the results we achieve. It is a process of inventing where we become "aware of the limitations of all grand frameworks, creating ways of coming up with new structures or thought and action suitable for particular occasions and monitoring the effects of these frames" (Snell\& Chak, 1998, p. 340). Within organisations, triple-loop learning is manifest through co-inventing where "members discover how they and their predecessors have facilitated or inhibited learning and produce new strategies and structures for learning" (Snell \& Chak, 1998, p. 340). From the above description, it is evident that triple-loop learning encompasses all of the disciplines of a learning organisation: there is a process of self-examination where individuals examine their purpose and the way they do things which relates to personal mastery. Mental models are reflected on and there is a process of co-inventing which involves team learning and building shared vision. The discipline of systems thinking integrates the other four disciplines in the triple-loop learning process and considers how these disciplines impact the system that the organisation operates in.

Triple-loop learning is a demanding process and inherent in this learning is critical reflection and introspection, requiring organisation members to think about how they think that impacts on what they do or are. Organisations or their members may not be open to this process. The founders or managers and directors may see this process as challenging them directly (Ram \& Holliday, 1993) and are "often averse to risk such basic questioning" (Altman \& Iles, 1998, p. 46). Furthermore, triple-loop learning may be resisted by organisation members where the association is made that the individual is part of the organisation and if the organisation is to change in a profound way, individuals, too, are to change and this may be an uncomfortable process - especially for individuals who come to work to earn money, rather than to experience profound change (Torbert, 1994). Some may be cynical and refer to spiritual organisations as being places to experience profound change, not business organisations. However, tripleloop learning is valid if the way organisations conduct business is fundamentally influenced by the methodology that is impressed in its practice. If the methodology promotes, for example, a certain process of learning, while what organisation members aspire to requires a different process of learning, individuals within the organisation may experience conflict between the two processes. By examining the 
root embedded in the methodology, this conflict can be understood and the processes of learning examined as part of the rationale of the organisation.

Communities of practice are, simply put, "groups of people informally bound together by shared expertise and passion for a joint enterprise" (Wenger \& Snyder, 2000, p. 139) and these groups "share their experiences and knowledge in free-flowing, creative ways that foster new approaches to problems" (Wenger \& Snyder, 2000, p. 140). Communities of practice consist of newcomers and old-timers (the masters or experts) within the community. Newcomers learn the practices of the community through legitimate peripheral participation and become old-timers through increasing centripetal participation (Lave, 1991). Competences are developed by newcomers as they engage in, commit and contribute to joint enterprise; build the community through relationships of mutual engagement; and participate in a shared repertoire of communal resources (language, routines, artefacts, tools, styles, stories, etc.) (Wenger, 1998; 2000). Communities of practice can contribute to the discipline of personal mastery as newcomers develop their identity as a practitioner and become a full participant in the community while they learn the practices, skills and knowledge of the community (Lave, 1991). Through engaging in a shared repertoire of communal resources, a community of practice opens itself for the discipline of mental models. If the community is reflective on its repertoire, it is able to understand "its own state of development from multiple perspectives, reconsider assumptions and patterns, uncover hidden possibilities, and use this self-awareness to move forward" (Wenger, 2000, p. 230). Concerning building shared vision, communities of practice can develop this discipline by encouraging alignment of its members through "a mutual process of co-ordinating perspectives, interpretations and actions" to realize higher goals (Wenger, 2000, p. 228).

Links can be seen between communities of practice and the discipline of team learning. A team is a social unit engaged in collective learning and activity. Teams provide sites for the cross-fertilization of ideas and for setting learning norms (Altman \& Iles, 1998; Senge, 1990), and can consist of "people who need one another to act" (Senge, 1990). Teams can be either formal or informal (Altman \& Iles, 1998). Wenger (1998) and Wenger and Snyder (2000) state that communities of practice are informal, organise themselves, establish their own leadership; are defined by their knowledge rather than by task; and exist because participation in the community adds value to its members, not because they are institutionally mandated. Although communities of practice should not be enforced as this often proves to be unsuccessful, managers can encourage these communities by bringing the "right people together", providing an infrastructure in which communities can thrive and measuring the communities' value in non-traditional ways (Wenger \& Snyder, 2000, p. 140). By doing this, the discipline of team learning through informal teams, as communities of practice, can be encouraged in the learning organisation (McDermott, 1999). Communities of practice can also contribute to the discipline of systems thinking as members can be encouraged to think of themselves as a member of not only their community, but of a larger community, such as their workplace and so see themselves as connected to the larger "whole" (Lave, 1991; Wenger, 2000). Communities of practice appears to be a theory that can be implemented in organisations in order for them to be learning ones (Cooper, 2006; Cooper, 2009), as the tenets of the theory provide opportunities for the disciplines of a learning organisation to be practised.

Small business sustainability: The disciplines of a learning organisation being practised by its members can contribute to a business being sustainable, but there are other factors that contribute to sustainability. Small business sustainability is an area of study itself, and the challenges that small businesses face is an area worth considering. The concept of sustainability is adapted from Zegarowski (2006): sustainability is a company's ability to generate long-term value through mutually beneficial relationships with stakeholders, in other words its ability to survive. There are many challenges to small business sustainability, with external factors that include economic, market, labour, infrastructure, social, finance and legislation being some of them. Economic factors include high inflation rates; low growth rates and declining exchange rates; high unemployment and low confidence affecting sales, revenue and market potential for small businesses (Olawale \& Garwe, 2010; Smit \& Watkins, 2012). Market factors include competing against large organisations, resource constraints, communication and networking. The greatest of these challenges is the South African market in which small businesses operate, often having to compete with larger organisations in the same market. They also have to compete with large organisations for labour (Cant, 2012; Painter-Morland \& Dobie, 2009; Sawers, Pretorius \& Oerlemans, 2008; Smit \& Watkins, 2012). South Africa also has a skills shortage in the labour market and more recently, many strikes in the mining sector (Mohsam \& van Brakel, 2011). Small businesses often have 
high staff turnover, affecting productivity, and as they are small, often lack capacity (Painter-Morland \& Dobie, 2009).

Another challenge is the cost of internal and external infrastructure, such as the high cost of technology and increasing cost of petrol and electricity (Olawale \& Garwe, 2010). Crime and corruption are social factors that inhibit small business sustainability. In fact, most robberies take place on small business premises. As a result, small businesses tend to focus on operational rather than strategic issues (Olawale \& Garwe, 2010; Painter-Morland \& Dobie, 2009). Finance is an important factor and the management of this element contributes greatly to the sustainability of small companies. Cash flow management is key and provides a challenge for small companies (Mohsam \& van Brakel, 2011; Neneh, 2012; Olawale \& Garwe, 2010; Smit \& Watkins, 2012). Many small businesses experience the South African environment as over-regulated and cannot afford to put the required compliance measures in place. Some regulations that small businesses find burdensome are the process to become a Value Added Tax (VAT) vendor; multiple taxation; and Broad-Based Black Economic Empowerment legislation (referred to locally as BEE) (Gleason, 2012; Painter-Morland \& Dobie, 2009), the latter being unique to South Africa. BEE legislation is intended to bring about equity amongst all race groups in South Africa. The BEE scorecard is used to measure the compliance of organisations against BEE legislation. Companies can be scored as Level 1 to Level 8 contributors, or non-compliant contributors. The lower the number of the level, the more compliant companies is to BEE legislation (Political Analysis South Africa, 2011-2012). BEE legislation was undergoing review in 2013. Amendments were released in October 2012 and a public comment process had taken place. Analysts anticipate it will take approximately two years to finalise the amendments before implementation (Laher, 2012). These amendments can be seen in Table 2 .

Table 2: Company bands on the BEE scorecard

\begin{tabular}{|c|c|c|c|c|}
\hline $\begin{array}{l}\text { Type of } \\
\text { enterprise }\end{array}$ & $\begin{array}{l}\text { Current annual } \\
\text { turnover }\end{array}$ & $\begin{array}{l}\text { Proposed } \\
\text { annual turnover }\end{array}$ & $\begin{array}{l}\text { Required } \\
\text { scorecard } \\
\text { elements } \\
\text { current }\end{array}$ & $\begin{array}{l}\text { Required scorecard } \\
\text { elements } \\
\text { proposed }\end{array}$ \\
\hline $\begin{array}{l}\text { Exempt Micro } \\
\text { Enterprises } \\
\text { (EMEs) }\end{array}$ & $\begin{array}{l}\text { Less than R5 } \\
\text { million } \\
( \pm \text { US } \$ 500000)\end{array}$ & $\begin{array}{l}\text { Less than R10 } \\
\text { million } \\
( \pm \text { US } \$ 1000000)\end{array}$ & $\begin{array}{l}\text { Not required to } \\
\text { complete }\end{array}$ & $\begin{array}{l}\text { Indicate the level of } \\
\text { black ownership }\end{array}$ \\
\hline $\begin{array}{l}\text { Qualifying Small } \\
\text { Enterprises } \\
\text { (QSEs) }\end{array}$ & $\begin{array}{l}\text { Between } \\
\text { million } \\
\text { US\$500 000) and } \\
\text { R35 million } \\
( \pm \text { US\$3 } 500000)\end{array}$ & $\begin{array}{l}\text { Between } \\
\text { million } \\
( \pm \text { US\$1 } \\
\text { and R50 million } \\
( \pm \text { US\$5 } 0000000)\end{array}$ & $\begin{array}{l}\text { Four of the seven } \\
\text { BEE scorecard } \\
\text { elements }\end{array}$ & $\begin{array}{l}\text { All five elements of } \\
\text { the BEE scorecard }\end{array}$ \\
\hline $\begin{array}{l}\text { Generic } \\
\text { Enterprises }\end{array}$ & $\begin{array}{l}\text { More than R35 } \\
\text { million } \\
\text { ( } \pm \text { US\$3 } 500000 \text { ) }\end{array}$ & $\begin{array}{l}\text { More than R50 } \\
\text { million } \\
( \pm \text { US\$5 } 000000 \text { ) }\end{array}$ & $\begin{array}{l}\text { All seven } \\
\text { elements of the } \\
\text { BEE scorecard }\end{array}$ & $\begin{array}{l}\text { All five elements of } \\
\text { the BEE scorecard }\end{array}$ \\
\hline
\end{tabular}

(Government Gazette No. 29617 and 35754)

Small businesses fall in the Exempt Micro Enterprises (EME) and Qualifying Small Enterprises (QSE) bands. Some of the amendments are favourable for small businesses, while others may present a challenge. For example, favourable aspects are the increase in turnover for exemption, but a challenge may be the proposed scorecard element of compliance to all elements of the scorecard, impacting on their rating. The level of black ownership can impact on the rating of small businesses and may cause ratings to drop if there is not sufficient black ownership - currently EMEs (which tend to be small organisations) are awarded Level 4 status, and Level 3 if they are more than 50\% black-owned. With the proposed amendments, $50 \%$ black ownership will give companies Level 2 status, and $100 \%$ black ownership a Level 1 status (Government Gazette No. 35754). Small businesses experience the cascade effect of the supply chain - if they have a high BEE level rating, they are viewed more favourably by larger companies they supply. In turn, these companies are thus better able to meet their BEE targets (Horwitz \& Jain, 2011). If small companies are not BEE compliant, their sustainability may be threatened. With regard to legislation (the regulatory environment), lifelong learning has become a priority in South Africa. This can be seen through the adoption of a framework for lifelong learning by the government in 1994 that mirrors international trends (Walters, 2000, p. 202). The government's focus on lifelong learning allows individuals disadvantaged by apartheid the opportunity to learn and develop globally-recognised skills (Walters, 2000, p. 202). This legislation includes the Skills Development Act No. 97 of 1998, the Skills 
Development Levy Act of 1999, the National Qualifications Framework (NQF) Act No. 67 of 2008 and the South African Qualifications Authority (SAQA) Act of 1995.

If legislation is encouraging companies to develop their employees, then companies within South Africa, which comply with or embrace the legislation, should be learning organisations. However, making training and development initiatives accessible to all staff does not necessarily mean that Senge's (1990) disciplines of a learning organisation are being practised or that the environment is that of a learning organisation. Legislation may regulate learning in organisations, but it does little to overcome the attitudes of individuals in organisations towards learning and each other. This leads to the role of internal factors of the organisation that can encourage a company to be a learning organisation. In order for the disciplines of a learning organisation to be practised, internal factors such as the organisational culture and leadership should encourage these practices. These factors also play a pivotal role in creating the environment for organisations to be sustainable. The organisational culture of a learning organisation should be one that values learning and reflects a "learning culture" (Farago \& Skyrme, 1995). Senge (1990) sees leaders as designers, stewards and teachers - which are characteristics of servant leadership, where leaders naturally want to serve to create an empowering environment for organisation members. Servant leadership contributes to the development of the five learning disciplines. Leaders create a learning culture. Leaders who exhibit these qualities set up an environment that is able to support personal growth as well as produce business results (Dess \& Picken, 2000, p. 22). With this literature in mind, I entered my research site.

\section{Methodology}

The methodology used was a qualitative, ethnographic case study approach (Merriam, 2009). An ethnographic case study approach describes a group or community (Bickman \& Rog, 1998) and looks at multiple interpretations of reality within the community being researched. This approach suited the paradigm of a learning organisation, as the essence of a learning organisation considers how individuals interpret their reality and how this interpretation can contribute to the development and sustainability of the organisation (Senge, 1990). An interactive model was employed that encouraged an iterative process and allowed me to review my methods, context, instruments, and purpose related to the research questions during the research periods (Maxwell, 1996). Ethical clearance was gained from the research site (small company) prior to commencing research and the identity of all respondents remained confidential for reporting purposes. A multi-method approach was used to collect data (Bickman \& Rog, 1998; Chilisa \& Preece, 2005; Denzin \& Lincoln, 1998; Hartley, 2004; McMillan \& Schumacher, 2006; Rule \& John, 2011; Yin, 2003). The methods were focused on identifying disciplines of a learning organisation practised by the research site and themes related to learning and sustainability. These instruments were observations, document analysis, questionnaires, transect walks, auto-photographs, focus groups and interviews.

During observations, I took notes of what I was observing in the work environment, for example the way staff went about their work, the way they interacted with each other, their actions and behaviours at their work consoles or in meetings, and so forth to "try [to] understand the patterns of behaviour and culture from the participants' perspective" (Rule \& John, 2011, p. 81). Using open coding, I then coded my observations into categories according to the five disciplines. Identifying the behaviours related to the disciplines was based on the descriptions provided by Senge (1990). Any observations that did not belong in these categories were considered in terms of additional categories, such as displays of trust, concern, care, encouraging participation and taking ownership. Thus open and axial coding was employed (Creswell, 1998; Rule \& John, 2011). The categories of codes were further analysed in the process of selective coding and the categories were examined for further coding (Creswell, 1998), for example some additional categories were narrowed into categories of organisational culture and leadership.

In analysing company documentation (company profile, performance appraisals, business and marketing strategy, consulting methodology, policy statements and any other relevant documentation provided, such as reports from surveys conducted by external consultants), I attempted to follow a similar process to the one described above. I looked for themes relating to the learning disciplines and coded these. I also identified additional themes in the company's documentation relating to their espoused practices and beliefs. This analysis assisted me in identifying whether the organisation claimed to be a learning organisation, be it overtly or covertly, and what wording indicated this claim. I was also able to identify information that could be probed during interviews to gain a better understanding of the organisation 
and its context. Document analysis was undertaken in both research periods of 2008 and 2012 as the company had reviewed and was in the process of reviewing its documentation after a branding survey and report had taken place. I attempted to gauge how the documentation had changed in light of the branding exercise as this provided insight into how the organisation adopted the concept of a learning organisation.

The questionnaires were confidential and completed by 60\% of the staff in 2008. Questionnaires in 2012 were completed by staff employed over the entire research period and their responses were compared and analysed to their responses in 2008 to identify if and how the organisation had changed over the period in terms of its learning characteristics. The questionnaires were structured with categories related to the learning disciplines and included a general section that covered information concerning the organisational culture and leadership. The questionnaires included a count for the closed questions and the different categories in order to identify a correlation between the counts and the learning disciplines. Respondents were requested to select a count for the responses between 1 (strongly agree) and 5 (strongly disagree). I counted the responses to the various categories and calculated the average of these categories for each respondent. Responses to the open ended questions were analysed and coded according to themes and categorised. The questionnaires, particularly the open ended questions, were helpful in understanding the context of the case (Rule \& John, 2011) and in identifying discrepant data that provided information for further probing during interviews, such as perceptions of the company's culture.

Transect walks took place in 2012 as an additional ethnographic research method as these provide an understanding of the environment from the perspective of an informant where the informant points out things in the environment that he/she considers to be significant as "this form of a guided tour allows participants to show the researcher issues of importance, concern or pride while explaining the history and impact of various landmarks and developments in their lives and their immediate context" (Rule \& John, 2011, p. 69). Participants were requested to volunteer to take me on a transect walk of the site, and in instances, participants were requested to do so to allow for "a more diverse range of issues and understandings to be captured" (Rule \& John, 2011, p. 69).

Auto-photography was also used as an additional research method in 2012 as it "can overcome language and cultural barriers between researcher and participants and ... it can help tap into unconscious and unquestioned domains of experience and beliefs" (Rule and John, 2011, p. 70). This method assisted in unearthing the mental models of participants and provided insight into this and other disciplines of a learning organisation as experienced by participants. Another reason for incorporating auto-photography is because sometimes "it is impossible to truly 'say' something" (Creswell, 2007, p. 179). This method encouraged all voices to be heard, in different ways. Disposable cameras were given to all participants and they were requested to capture any image or instance that they saw as significant to the area of study, with the theme of "we are a learning organisation". This theme was quite open-ended in order to understand how participants interpreted the concept in their context. The photographs were then used as the basis of a focus group discussion where participants grouped the photographs according to themes, and dialogue was encouraged to generate new understandings of participants' experiences (Creswell, 2007).

A focus group was held in 2012 with volunteer staff members. The auto-photographs, which reflected similar aspects to the transect walks, formed the basis of discussion. I handed the photographs to the participants and requested that they group the photographs according to themes to answer the question: "Describe how your photos illustrate that your company is a learning organisation". The photographs were numbered so that these could be referred to during discussion. The participants were involved "in a process of dialogue aimed at making sense of the visual data" (Rule \& John, 2011, p. 83). I had an additional set of questions to initiate and prompt further discussion, which I facilitated, to move "participants from literal descriptions of images into deeper exploration of significance and meaning of the images" (Rule \& John, 2011, p. 84). Focus group discussions were also analysed according to content and themes (Rule \& John, 2011).

Semi-structured interviews were conducted in 2008 with two of the three directors, three staff and one intern, and in 2012, an executive, a manager and two staff was interviewed. A manager and one staff member, both of whom had been working with the company during the entire research period, were included in the 2012 cohort. The semi-structured approach allowed me to discuss certain 
themes/questions, and I was also able to follow a line of discussion as I felt necessary. These lines of discussion were coded and categorised across all interviews in order to identify further themes or discrepant data that would contribute to findings. My challenge, as researcher, was to tie back the data to the learning theories embedded in Senge's (1990) learning disciplines.

\section{Results}

The results from all the instruments revealed that members viewed their organisation as being a learning one that practised all the disciplines. Discrepant data revealed that the owner-manager (leader) personally experienced the discipline of mental models less, which, by his own admission, could be related to his functioning more at an operational than strategic level. Triple-loop learning and communities of practice were learning theories with which staff members regularly engaged with. In addition to the learning theories being incorporated into day-to-day practice, the leadership and organisational culture played a key role in encouraging and enabling learning. The research results in Table 3 provide a snapshot of incidences that reflected the learning theories of triple loop learning and communities of practice in action. The company used various learning methods and strategies that were consistent with these learning theories. Use of these methods and strategies could be a contributing factor to its ability to practise the learning disciplines. Furthermore, staff appeared to employ these theories unconsciously during their daily course of work and activities.

Table 3: Research instrument/settings and related learning theories

\begin{tabular}{|c|c|c|c|c|}
\hline $\begin{array}{l}\text { Learning } \\
\text { theory } \\
\text { evident }\end{array}$ & $\begin{array}{l}\text { Research } \\
\text { instrument }\end{array}$ & Instrument/ Setting & Interpretation / Comment & $\begin{array}{l}\text { Learning } \\
\text { discipline } \\
\text { related to }\end{array}$ \\
\hline $\begin{array}{ll}\text { Triple loop } \\
\text { learning }\end{array}$ & $\begin{array}{l}\text { Observations } \\
\text { Questionnaires } \\
\text { Document analysis } \\
\text { Transect walks } \\
\text { Auto photography } \\
\text { Focus group } \\
\text { Interviews }\end{array}$ & $\begin{array}{l}\text { The research site underwent a } \\
\text { branding exercise during which } \\
\text { it examined who it was, clients' } \\
\text { perception of the company, what } \\
\text { its products and service offerings } \\
\text { were and how it needed to } \\
\text { adapt/adjust these factors to } \\
\text { continually meet its clients' } \\
\text { needs. Focus group and } \\
\text { interview respondents } \\
\text { commented on their capacity to } \\
\text { examine what the company was } \\
\text { and their purpose for existing. } \\
\text { Transect walks and auto } \\
\text { photography also revealed that } \\
\text { artefacts related to the } \\
\text { organisational rationale and } \\
\text { contexts were important to } \\
\text { respondents, as well as the } \\
\text { process of designing these. }\end{array}$ & $\begin{array}{l}\text { The company displayed its } \\
\text { capacity to question what it was, } \\
\text { how that impacted on what it did, } \\
\text { how it acted and the results it } \\
\text { achieved. Organisation members } \\
\text { considered their roles as } \\
\text { individuals and how they } \\
\text { contributed to the organisation } \\
\text { and its future. }\end{array}$ & $\begin{array}{l}\text { Personal } \\
\text { mastery } \\
\text { Building shared } \\
\text { vision } \\
\text { Mental models } \\
\text { Team learning } \\
\text { Systems } \\
\text { thinking }\end{array}$ \\
\hline $\begin{array}{l}\text { Communities } \\
\text { of practice }\end{array}$ & $\begin{array}{l}\text { Observations } \\
\text { Questionnaires } \\
\text { Transect walks } \\
\text { Auto photography } \\
\text { Focus groups } \\
\text { Interviews }\end{array}$ & $\begin{array}{l}\text { The research site was a } \\
\text { community of practice and } \\
\text { naturally seemed to adopt this } \\
\text { theory in most of their dealings. } \\
\text { In a staff meeting, staffs were } \\
\text { requested to complete a form } \\
\text { indicating what training they } \\
\text { needed and what training they } \\
\text { could give. In the office, staff } \\
\text { would often request information } \\
\text { from another that they knew to } \\
\text { be a 'master' in the area. The } \\
\text { theme of "becoming/being a } \\
\text { master" was a prominent one in } \\
\text { all research instruments with } \\
\text { respondents referring to } \\
\text { opportunities to learn from one } \\
\text { another as being key in the } \\
\text { organisation. }\end{array}$ & $\begin{array}{l}\text { The research site encouraged a } \\
\text { free-flow of information and many } \\
\text { staff commented that they viewed } \\
\text { knowledge as being shared and } \\
\text { not owned. There was recognition } \\
\text { of masters (experts) who could be } \\
\text { accessed to share their } \\
\text { knowledge. }\end{array}$ & $\begin{array}{l}\text { Personal } \\
\text { mastery } \\
\text { Mental models } \\
\text { Building shared } \\
\text { vision } \\
\text { Team learning } \\
\text { Systems } \\
\text { thinking }\end{array}$ \\
\hline
\end{tabular}

With regard to sustainability, the organisation experienced growth during the research periods, as can be seen in Table 4. There was a drop in turnover in 2010 with projects that had been planned in 2008 being cancelled, seemingly as a result of the global credit crisis. However, there is over a 200 percent increase in 
turnover for 2011 and an upward trend for 2012. It seemed that staff at the organisation had sustainability as a focus, evidence of which was seen in data collected using various research instruments, especially in the company documentation. Documentation made references and inferences to sustainability, which is likely to have influenced the organisation's practice - its products and services were aimed at the sustainability of its clients, and this mindset is likely to have been adopted by consultants internally.

Table 4: Turnover figures for research site during research period (2008-2012)

\begin{tabular}{|c|c|}
\hline Year & Turnover \\
\hline 2008 & R11 579006 ( \pm US \$1 157900$)$ \\
\hline 2009 & R16 617565 ( \pm US \$1 661756$)$ \\
\hline 2010 & R14 $099302( \pm$ US \$1 409930$)$ \\
\hline 2011 & R32 $837562( \pm$ US \$3 283756$)$ \\
\hline 2012 & R41 460558 ( \pm US \$4 146055$)$ \\
\hline
\end{tabular}

Meetings and staff interactions had a strong focus on marketing the business, finances (being cashpositive with no overdrafts) and presenting quality products and services. The managing director played a role in both - conducting client visits and reviewing products and services before they were offered to clients. He saw these as contributors to repeat business. The company, being small, was fundamentally connected to the owner-manager, who had many demands placed on him. The owner-manager (managing director/leader) commented that he tended to be too operational, rather than strategic, in his approach, resulting from his being 'hands-on'. He was investigating setting up a management team or board of directors to support him, and allow him time for strategic thinking. The organisation members were aware of the leader's challenges and the organisation referred to it as the 'founder's trap'. Despite being caught in the 'founder's trap', the leader largely practised servant leadership which encouraged a learning culture and the practice of the learning disciplines. He would display servant leadership by listening to staff and making time to engage with them by ensuring that they had the necessary tools on hand to perform their function and allowing to them to complete their tasks without interference, while being willing to discuss ideas. He was generous with information, and staff commented that they learnt much from him. The owner-manager encouraged questioning by asking questions himself - not in an intimidating, micro-management approach - but in an enquiring way. Staff interpreted his action as being key in setting up the learning culture in the company and the company being a learning organisation.

Staff comments included in various research instruments that demonstrated that the company was a learning organisation, displayed this culture and was sustainable, include:

We're a strong team that works well together. We understand one another and help each other and people offer to help. Our relationships tend to be casual and not as formal as you would find in big companies (questionnaire: open question response).

Ours is a learning organisation. We are free to talk and tap into staff identified as 'containers of knowledge'. We are also given the opportunity to learn and become a source of knowledge ourselves. We are given opportunities to excel, make mistakes and share with others. Through open communication in the open plan office you can start a discussion. If you get stuck on how to resolve an issue being discussed, someone usually chips in to help (questionnaire: open question response).

What I enjoy about working here is the company culture, learning exposure or opportunity, room for growth (questionnaire: open question response).

Our company is sustainable because of its model - the model is sellable and there are enough clients who need our services (interview comment).

The company is constantly giving opportunities to learn new skills, etc. to be able to adapt to a changing environment (focus group comment).

\section{Conclusion and Recommendations}

The research site was a learning organisation, which engaged various learning theories that developed the learning disciplines. The learning theory of communities of practice was naturally used often and 
triple-loop learning was also evident. This finding links to the theoretical framework where these two learning theories assist with developing all five of the learning disciplines. The organisation continued to function over the two research periods, and even experienced financial growth. Post-2008 was a challenging period with the global credit crisis taking place, but the research site continued to sustain itself. The organisation was aware of the many external challenges that it faced and paid attention to how to deal with these, with a key focus on marketing. The business was in a "cash positive" position with no overdrafts and a strong focus on quality that contributed to repeat business. As the organisation was a small company, it was intrinsically connected to the owner-manager, with many demands placed on him. The owner-manager (managing director/leader) needed a 'critical friend' or mentor with whom he could discuss issues at a strategic rather than an operational level. Despite these challenges, the ownermanager was able to encourage a learning culture within the company.

The recommendations are based on comments made during data collection. To ensure that the organisation is able to continue practising the learning disciplines or improve its practice, as well as its sustainability, it should:

- Encourage shared learning through more frequent information-sharing sessions. These could be formal (such as staff meetings) and informal (such as through social days).

- Team members should have varied responsibilities on projects so that they could learn and develop from these responsibilities.

- Project review sessions should be held at the close of projects. All organisation members should attend these so that they can translate lessons learnt from one project to another. This would not only contribute to the learning that took place, but could also save costs by avoiding similar mistakes and the company could be more profitable, contributing to its existence into the future (sustainability).

- Frequent management meetings should be held to encourage the sharing of information and the building of a shared vision at both an operational and a strategic level. The management team could also absorb some of the responsibilities from the owner-manager so that he could become more strategically focused.

- Attend to its BEE rating - the company had a BEE Level 1 rating. However, when its black partner resigned its BEE rating risked dropping. The company would need to explore avenues to retain its BEE rating at Level 1 and continue to contribute to it being a preferred partner, owing to its high rating.

The recommendations above are linked to the development of the learning disciplines, the incorporation of learning theories of triple-loop learning and communities of practice in its daily operations, and sustainability. This small organisation researched practised the five disciplines and used an eclectic range of learning methods and strategies that were consistent with various learning theories. It seemed to do this in a natural, organic way. My expectation was that it would need a consultant or learning specialist to advise on the disciplines and learning theories of a learning organisation, but that was not the case. The leadership and culture had created the environment for a learning organisation. The small company was sustainable through difficult economic times and its focus on learning appeared to be a contributing factor to sustainability. It was not the only factor, though. In the context of this small business, quality, financial management and marketing also played an important role. The company should still be able to provide employment and contribute to the South African GDP for years to come if it continues as a learning organisation. The study was not without limitations. These included the philosophical paradigm of the methodology; the demands placed on a sole researcher, such as my ability to participate in various settings, awareness of myself and the participants, and demands resulting from the design of the research; the presence of multiple voices in the group; the possibility of overlooking or ignoring data and the value of knowledge gained with regard to a single case being researched (Atkinson \& Hammersley, 1998; Eisenhart, 2001; Rule \& John, 2011). A multi-method approach was adopted to verify data that was collected in an attempt to overcome some of these limitations.

As a case study approach is an emergent design (Yin, 2003), as researcher, I needed to be aware of how the research informed further decisions, and thus needed continually to make links between data collected and next steps. This was mostly based on gut-feel so the decisions made were largely intuitive. As the study was based on a single site, the correctness of these decisions could not be examined against another site (Merriam, 2009). The case study is based on a single case, which allowed for in-depth study of the case, but there is a lack of a comparative dimension within the study (Rule \& John, 2011). Being an ethnographic case study, the findings of the study cannot be generalised to the entire population from which the sample was selected but it would be reasonable to interpret results as valid to organisations 
similar to the site studied (McMillan \& Schumacher, 2006). The study was unique in that it researched a single site of a small South African company as a learning organisation, using the novel approach of an ethnographic case study, to investigate whether learning theories contributed to Senge's (1990) learning disciplines and how this contributed to the organisation's sustainability. The study can be expanded, and recommendations for further study include researching a small company as a learning organisation in a different sector, and researching a small company as a learning organisation using different research design/methodology/instruments.

\section{References}

Altman, Y. \& Iles, P. (1998). Learning, leadership, teams: corporate learning and organisational change. Journal of Management Development, 17(1), 44-55.

Bickman, L. \& Rog, D. J. (1998) Handbook of Applied Social Research Methods. London: Sage Publications.

Black Economic Empowerment Act of 2003. Available at www.thedti.gov.za (accessed 14 August 2007).

Brookfield, S. D. (2000). The Concept of Critically Reflective Practice. In Wilson, A.L. and Hayes, E.R. (Eds). Handbook of Adult and Continuing Education. San Francisco: Jossey-Bass Publishers.

Cant, M. (2012). Challenges faced by SMEs in South Africa: Are marketing skills needed? International Business and Economics Research Journal, 11(10), 1107-1116.

Chilisa, B. \& Preece, J. (2005). Research Methods for Adult Educators in Africa. Cape Town: Pearson Education, Inc.

Cooper, L. (2006). The trade union as a 'learning organisation'? A case study of informal learning in a collective, social-action organisational context. Journal of Education, 39, 27-46.

Cooper, L. (2009). A new perspective on the 'learning organisation': A case study of a South African trade union. In Cooper, L. and Walters, S. (Eds). Learning/Work. Turning work and lifelong learning inside out, pp 284-295. Cape Town: HSRC Press.

Dess, G. G. \& Picken, J. C. (2000). Changing roles: Leadership in the $21^{\text {st }}$ Century. Organization Dynamics, 3 , 18-34.

Farago, J. \& Skyrme, D. J. (1995). The Learning Organization. David Skyrme and Associates. Available at: www.skyrme.com./insights/3lrnorg.htm (accessed on 29 October 2007).

Fenwick, T. (2001). Questioning the concept of the learning organization. In Paechter, C.; Preedy, M.; Scott, D. and Soler, J. (Eds). Knowledge, Power and Learning. London: Paul Chapman Publishing Ltd.

Garvin, D. A. (1993). Building a Learning Organization. Harvard Business Review, 4, 78-91.

Gleason, D. (2012). Codes could bring BBBEE to a halt. Available at: http://www.bdlive.co.za/opinion/columnists/2012/10/16/codes-could-bring-bbbee-to-a-halt (accessed on 12 December 2012).

Government Gazette No 29617: B-BBEE Codes of Good Practice. Available at: http://www.trevenna.net/bee/beemaincodes.htm (accessed on 5 May 2011).

Government Gazette No 35754: Revised Broad-Based Black Economic Empowerment Codes of Good Practice. Available at: http://www.info.gov.za (accessed on 12 December 2012).

Hartley, J. (2004). Chapter 26: Case study research. In Cassell, C. and Symon, G. Essential guide to qualitative methods in organizational research. London: Sage Publications.

Hattingh, S. \& Smit, S. (2004). Building Learning Organisations to Enhance Competitiveness. Roadmap Series. Randburg: Knowres Publishing.

Horwitz, F. M., Bowmaker-Falconer, A. \& Searll, P. (1996). Human resource development and managing diversity in South Africa. International Journal of Manpower, 17(4/5), 134-151.

Isaacs, W. N. (1993). Taking Flight: Dialogue, Collective Thinking, and Organizational Learning. Organizational Dynamics, 22(2), 24-39.

Laher, I. (2012). New BEE codes for small business. The Citizen, 12 October. Available at: http://www.citizen.co.za/citizen/content/en/citizen/businessnews?oid=328693\&sn=Detail\&pi $\mathrm{d}=146848 \&$ New-BEE-codes-for-small-business

Lave, J. (1991). Situating Learning in Communities of Practice. In Resnick, L., Levine, J. and Teasley, S. (Eds) (1991). Perspectives on Socially Shared Cognition. Washington, DC: APA.

McDermott, R. (1999). Learning across Teams: The Role of Communities of Practice in Team Organisations. Knowledge Management Review, 2, 1-8.

Maxwell, J. A. (1996). Qualitative Research Design - An Interactive Approach. London: Sage Publications.

Merriam, S. B. (2009). Qualitative Research - A Guide to Design and Implementation. California: JosseyBass, Inc. Publishers.

Mezirow \& Associates (1990). Fostering Critical Reflection in Adulthood. San Francisco: Jossey-Bass Publishers. 
Mohsam, F. \& van Brakel, P. A. (2011). Information and knowledge sharing trends of small and mediumsized enterprises in the Western Cape, South Africa. SA Journal of Information Management, 13(1), 1-10.

National Qualifications Framework (NQF) Act, No. 67 of 2008. Available at: www.acts.co.za (accessed 18 July 2009).

Neneh, N. B. (2012). An exploratory study on entrepreneurial mindset in the small and medium enterprise (SME) sector: A South African perspective on fostering small and medium enterprise (SME) success. African Journal of Business Management, 6(9), 3364-3372.

Olawale, F. \& Garwe, D. (2010). Obstacles to the growth of new SMEs in South Africa: A principal component analysis approach. African Journal of Business Management, 4(5), 729-738.

Painter-Morland, M. \& Dobie, K. (2009). Ethics and sustainability within SMEs in sub-Saharan Africa: Enabling, constraining and contaminating relationships. African Journal of Business Ethics, 4(2), 219.

Political Analysis South Africa. (2011-2012). South Africa's revised BEE structures. Available at: http://www.politicalanalysis.co.za/2012/10/17/analysing-south-africas-revised-bee-structure/ (accessed on 12 December 2012).

Ram, M. \& Holliday, R. (1993). Relative Merits: Family Culture and Kinship in Small Firms. Sociology, $27(4), 629-648$.

Rogers, A. (2003). What is the difference? A new critique of adult learning and teaching. Leicester: The National Institute of Adult Continuing Education.

Rule, P. \& John, V. (2011). Your guide to Case Study Research. Pretoria: van Schaik Publishers.

SAQA Act of 1995. Available at: www.acts.co.za (accessed 14 August 2007).

SAQA. (2006). The National Qualifications Framework: An Overview. Available at: http://www.saqa.org.za/show.asp?include=saqa\%5Fextra/structure/nqf/overview01.html (accessed 18 July 2007; 11 May 2011).

Sawers, J. L., Pretorius, M. W. \& Oerlemans, L. A. G. (2008). Safeguarding SMEs dynamic capabilities in technology innovative SME-large company partnerships in South Africa. Technovation, 28, 171182.

Senge, P. M. (1990). The Fifth Discipline - The Art and Practice of the Learning Organization. London: Random House.

Skills Development Act No. 97 of 1998. Available at: www.acts.co.za (accessed 14 August 2007).

Skills Development Levy Act of 1999. Available at: www.acts.co.za (accessed 14 August 2007).

Smit, Y. \& Watkins, J. A. (2012). A literature review of small and medium enterprises (SME) risk management practices in South Africa. African Journal of Business Management, 6(21), 63246330.

Snell, R. \& Chak, A. M. (1998). The Learning Organisation: Learning and Empowerment for Whom? Management Learning, 29(3), 337-364.

The dti. Department: Trade and Industry. Republic of South Africa (n.d.). Integrated Strategy on the Promotion of Entrepreneurship and Small Enterprises. Available at: www.dti.org.za/smme/strategy.pdf (accessed 25 April 2009).

Tight, M. (1996). Key Concepts in Adult Education and Training. London: Routledge.

Torbert, W. R. (1994). Managerial Learning, Organisational Learning - A Potentially Powerful Redundancy. Management Learning, 25(1), 57-70.

Walters, S. (2000). Globalisation, Adult Education and Development. In Stromquist, N.P. and Monkman, K. (Eds). Globalisation and education: integration and contestation across cultures. USA: Rowman and Littlefield Publishers, Inc.

Wenger, E. (1998). Communities of Practice: Learning as a Social System. Systems Thinker, 9(5), 1-10.

Wenger, E. (2000). Communities of Practice and Social Learning Systems. Organization, 7(2), 225-246.

Wenger, E. C. \& Snyder, W. M. (2000). Communities of Practice: The Organisational Frontier. Harvard Business Review, 2, 139-145.

World Business Council for Sustainable Development and SNV (n.d.). Promoting Small and Medium Enterprises for Sustainable Development. Available at: www.wbcsd.org/web/publications/sme.pdf (accessed 25 April 2009).

Yin, R. K. (2003). Case Study Research - Design and Methods. Third Edition. London: Sage Publications.

Zegarowski, G. (2006). Corporate sustainability after Sarabanes-Oxley linking socio-political initiatives and small and medium-sized enterprises resources. International Journal of Disclosure and Governance, 4(1), $52-58$. 